\title{
EDUKASI PEMILAHAN SAMPAH SEBAGAI UPAYA PREVENTIF MENGATASI MASALAH SAMPAH DI LINGKUNGAN SEKOLAH
}

\author{
Anisza Ratnasari ${ }^{1}$, Imaniar Sofia Asharhani², Marchelia Gupita Sari ${ }^{3}$, Stefanus Rifaldo Hale ${ }^{4}$, \\ Hegar Pratiwi ${ }^{5}$ \\ 1,2,3,4,5 Program Studi Arsitektur, Institut Sains dan Teknologi Pradita, Tangerang \\ anisza.ratnasari@pradita.ac.id,imaniar.sofia@pradita.ac.id,marchelia.gupita@pradita.ac.id, \\ stefanus.rifaldo@student.pradita.ac.id, hegar.pratiwi@student.pradita.ac.id
}

\begin{abstract}
Abstrak
Upaya menjaga lingkungan sekitar harus bermula dari diri sendiri dengan melakukan hal-hal kecil. Edukasi kepada siswa mengenai permasalahan lingkungan akibat timbunan sampah diperlukan untuk menumbuhkan kesadaran siswa agar mereka lebih peduli dengan lingkungan sekitarnya. Partisipasi aktif siswa dapat dilakukan dalam budaya membuang sampah pada tempatnya. Namun demikian, karena banyaknya kategori sampah yang ada, perlu adanya edukasi kepada siswa tentang jenis-jenis sampah, yaitu; sampah organik, anorganik dan B3 (bahan berbahaya dan beracun) dan penanganannya. Siswa harus disosialisasi untuk meninggalkan cara lama yang hanya membuang sampah begitu saja, tetapi juga memberikan edukasi dan membiasakan siswa untuk memilah, memilih, dan mengkategorisasi sampah sekaligus melakukan pengembangan bank sampah sehingga memiliki nilai ekonomi. Bila hal tersebut dilakukan, maka praktek mengolah dan memanfaatkan sampah menjadi langkah nyata dalam mengelola sampah. Sosialisasi dilakukan dalam bentuk presentasi, pemutaran film, permainan / games dan kegiatan interaktif lainnya. Harapan kedepannya, kebiasaan kecil tersebut akan ditularkan dalam keluarga dan masyarakat sekitar yang memungkinkan mengurangi masalah lingkungan yang disebabkan oleh sampah.
\end{abstract}

Kata Kunci : pemilahan sampah, 3R, edukasi siswa sekolah, upaya preventif masalah lingkungan

\section{PENDAHULUAN}

Pengabdian kepada Masyarakat (PkM) merupakan salah satu dharma dari Tridarma Perguruan Tinggi yang wajib dilakukan semua sivitas akademika perguruan tinggi tidak terkecuali Program Studi Arsitektur sebagai bagian dari Institut Sains dan Teknologi Pradita. Darma pengabdian masyarakat diharapkan selaras dengan isu yang berkembang saat ini, sehingga penerapan teknologi terkini dapat langsung dirasakan manfaatnya oleh masyarakat.

Kegiatan ini merupakan bentuk pengabdian akademisi bekerja sama dengan TNI Manunggal Membangun Desa (TMMD) dalam bentuk kegiatan non-fisik. Kegiatan bertujuan untuk mengedukasi atau mensosialisasi kepada masyarakat, khususnya menyasar pada siswa di lingkungan sekolah SMA/K Yadika 10, Tangerang. Materi yang disampaikan antara lain tentang pentingnya memilah sampah berdasarkan jenis dan kategorinya.

Lingkungan Hidup dan Bencana 
Sampah merupakan sisa dari aktivitas manusia yang dianggap tidak berguna lagi dan merupakan material sisa yang tidak diinginkan setelah berakhirnya suatu proses. Sampah yang dihasilkan berasal dari aktivitas rumah tangga maupun dari kegiatan industri. Volume sampah yang dihasilkan semakin hari, semakin meningkat salah satu faktornya dikarenakan jumlah penduduk yang juga semakin meningkat. Data menunjukkan bahwa sampah yang dihasilkan Indonesia secara keseluruhan mencapai 175.000 ton per hari (https://geotimes.co.id), sehingga dengan asumsi bahwa jumlah penduduk sebanyak 258,7 juta orang (BPS, 2017b), setiap orang di Indonesia memproduksi sampah 0,67 kilogram per orang per hari. Dengan perkiraan setiap penduduk menghasilkan 0,52 - 0,7 kilogram sampah per hari, maka total sampah yang kita hasilkan sebesar 134,5 $-181,1$ ribu ton per hari atau setara 49,1 - 66,1 juta ton per tahun.

Sampah tersebut akan semakin meningkat bila tidak ada tindakan preventif dan pengelolaan yang baik. Banyaknya proses yang dilakukan membuat penimbunan sampah semakin tinggi, maka dari itu diperlukan proses yang dapat mengolah sesuatu yang tidak terpakai menjadi barang yang bermanfaat. Guna mempermudah proses pengolahan sampah, maka dibuatlah beberapa prinsip yang perlu diterapkan. Berikut adalah prinsip-prinsip yang bisa diterapkan dalam pengolahan sampah. Prinsipprinsip ini dikenal dengan nama 4M, yaitu: 1) mengurangi (reduce), meminimalisasi barang atau material yang kita pergunakan; 2) menggunakan kembali (reuse), memilah barang-barang yang bisa dipakai kembali, menghindari pemakaian barangbarang yang sekali pakai; 3) mendaur ulang (recycle), menggunakan kembali barang-barang yang sudah tidak berguna; 4) mengganti, meneliti barang yang kita pakai sehari-hari dengan menganti barang-barang yang hanya bisa dipakai sekali dengan barang yang lebih tahan lama.

Sampah terbagi menjadi 3 jenis, yaitu sampah organik, anorganik, dan B3 (Bahan Berbayada dan Beracun). Setiap jenis sampah memiliki karakter yang berbeda dan cara pengolahan yang berbeda pula, antara lain: 1) sampah organik yang berasal dari makhluk hidup, baik manusia, hewan, maupun tumbuhan. Sampah organik sendiri dibagi menjadi sampah organik basah, adalah sampah yang mempunyai kandungan air cukup tinggi. Contohnya kulit buah dan sisa sayuran. Kemudian sampah organik kering adalah bahan organik lain yang kandungan airnya kecil. Contoh sampah organik kering di antaranya kertas, kayu atau ranting pohon, dan dedaunan kering. 2) Sampah anorganik adalah sampah yang dihasilkan dari bahan-bahan non-hayati, baik berupa produk sintetik maupun hasil proses teknologi pengolahan bahan tambang atau sumber daya alam dan tidak dapat diuraikan oleh alam, Contohnya: botol plastik, tas plastik, kaleng. 3) Limbah B3 (Bahan Berbahaya dan Beracun) adalah setiap limbah yang mengandung bahan berbahaya atau beracun karena sifat, konsentrasi dan jumlahnya, baik secara langsung maupun tidak langsung dapat merusak lingkungan hidup atau membahayakan kesehatan manusia.

Menurut Undang-Undang Republik Indonesia No. 18 Tahun 2008 Tentang Pengelolaan Sampah, sampah B3 merupakan sampah spesifik yang meliputi: 1) sampah yang mengandung bahan berbahaya dan beracun; 2) sampah yang mengandung limbah B3; 3) sampah yang timbul akibat bencana; 4) bongkaran puing bangunan; 5) sampah yang secara teknologi belum dapat diolah; dan 6) sampah yang timbul secara periodik.

Edukasi mengenai jenis sampah dan pemilahan sampah tersebut disampaikan kepada siswa sekolah menengah atas dengan harapan mereka mampu melakukan penanganan lebih lanjut sampah dilingkungan sekolah mereka sehingga mampu menanggulangi dampak lanjut dari sampah.

Sosialisasi diberikan kepada siswa sekolah karena melihat pentingnya peran aktif pelajar untuk memulai aksi mencegah timbunan sampah disekitarnya. Dengan memberikan edukasi diharapkan siswa akan dapat menularkan kebiasaan baik kepada orang-oang disekitanya, baik keluarga, teman dan lingkungan mereka dengan membuang sampah dengan cara melakukan pemilahan.

Pemahaman mengenai kewajiban untuk menjaga lingkungan sekitar harus bermula dari diri sendiri dengan melakukan hal-hal kecil. Edukasi kepada siswa sekolah menengah atas mengenai Lingkungan Hidup dan Bencana 
permasalahan lingkungan akibat timbunan sampah diperlukan untuk menumbuhkan kesadaran siswa agar mereka lebih peduli dengan lingkungan sekitarnya. Partisipasi aktif siswa dapat dilakukan dalam budaya membuang sampah pada tempatnya. Namun demikian, karena banyaknya kategori sampah yang ada, perlu adanya edukasi kepada siswa tentang jenis-jenis sampah, yaitu; sampah organik, anorganik dan B3 (bahan berbahaya dan beracun) dan penanganannya. Siswa harus disosialisasi untuk meninggalkan cara lama yang hanya membuang sampah begitu saja, tetapi juga memberikan edukasi dan membiasakan siswa untuk memilah, memilih, dan mengkategorisasi sampah sekaligus melakukan pengembangan bank sampah sehingg amemiliki nilai ekonomi. Bila hal tersebut dilakukan, maka praktek mengolah dan memanfaatkan sampah menjadi langkah nyata dalam mengelola sampah. Kebiasaan kecil tersebut nantinya akan ditularkan dalam keluarga dan masyarakat sekitar yang memungkinkan mengurangi masalah lingkungan yang disebabkan oleh sampah.

Dari latar belakang diatas maka diperlukan pemahaman bagi para siswa mengenai pentingnya membuang sampah sesuai dengan kategorinya, yaitu: 1) mengetahui jenis dan kategori sampah yang sering mereka jumpai di lingkungan sekolah maupun masyarakat; 2) mengetahui bagaimana cara memilah sampah berdasarkan kategorinya; 3) mengetahui bagaimana cara pengolahan sampah, agar memiliki nilai lebih; 4) menumbuhkan kesadaran pada diri siswa mengenai pentingnya memelihara lingkungan sekitar dimulai dari membuang sampah pada tempatnya.

\section{METODE}

Kegiatan Pengabdian kepada Masyarakat $(\mathrm{PkM})$ ini merupakan bentuk pengabdian dosen dan mahasiswa Program Studi Arsitektur Institut Sains dan Teknologi Pradita yang bekerja sama dengan TNI (Tentara Republik Indonesia) dalam kegiatan TNI Manunggal Membangun Desa (TMMD) ke105. Dosen dan mahasiswa sebagai satuan tugas (satgas) TNI melakukan kegiatan non-fisik berupa edukasi atau sosialisasi kepada masyarakat, yaitu siswa di lingkungan sekolah SMA Yadika 10
Tangerang tentang pentingnya memilah sampah berdasarkan jenis dan kategorinya, sehingga mereka mampu melakukan penanganan lebih lanjut sampah dilingkungan sekolah mereka sehingga mampu menanggulangi dampak lanjut dari sampah.

Tabel 1. Urutan Kegiatan

\begin{tabular}{cll}
\hline WAKTU & \multicolumn{1}{c}{ KEGIATAN } & PIC \\
\hline $09.15-09.25$ & $\begin{array}{l}\text { Pembuka dan } \text { overview } \\
\text { sampah di lingkungan sekitar }\end{array}$ & Hegar \\
$09.25-09.35$ & $\begin{array}{l}\text { Presentasi tentang sampah di } \\
\text { lingkungan sekitar dan bahaya }\end{array}$ & Gupita \\
& $\begin{array}{l}\text { penumpukan sampah bagi } \\
\text { lingkungan }\end{array}$ & \\
$09.35-10.00$ & $\begin{array}{l}\text { Pemutaran film dokumenter } \\
\text { tentang bahaya sampah }\end{array}$ & Stefanus \\
$10.00-11.00$ & $\begin{array}{l}\text { Games: pengelompokan jenis } \\
\text { sampah dan pemilahannya }\end{array}$ & Anisza \\
& Review dan pembagian & Hegar \\
& doorprize & \\
\hline
\end{tabular}

Sosialisasi atau edukasi diberikan kepada siswa sekolah karena melihat pentingnya peran aktif pelajar untuk memulai aksi mencegah timbunan sampah disekitarnya. Dengan memberikan edukasi diharapkan siswa akan dapat menularkan kebiasaan baik kepada orang-oang disekitanya, baik keluarga, teman dan lingkungan mereka dengan membuang sampah dengan cara melakukan pemilahan.

Metode penyampaian edukasi mengenai sampah diawali dengan sistem pengajaran ceramah, yakni dengan menyampaikan informasi dan pengetahuan secara lisan kepada sejumlah siswa yang pada umumnya mengikuti secara pasif.

Metode ceramah dipilih untuk menyampaikan konsep tentang lingkungan hidup, klasifikasi sampah, peran serta perempuan dalam pengelolaan lingkungan hidup, serta pengelolaan sampah rumah tangga dengan metode komposting Materi yang disampaikan ialah mengenai informasi keberadaan sampah di lingkungan sekitar dan bahawa penumpukan sampah bagi lingkungan. Lingkungan Hidup dan Bencana 
Dilanjutkan dengan menonton film dokumenter tentang bahaya sampah bagi manusia. Selama ceramah berlangsung, siswa diperbolehkan bertanya dan berinteraksi dengan pemberi informasi. Kegiatan ini diielaskan pada Gambar 1-Gambar 3.

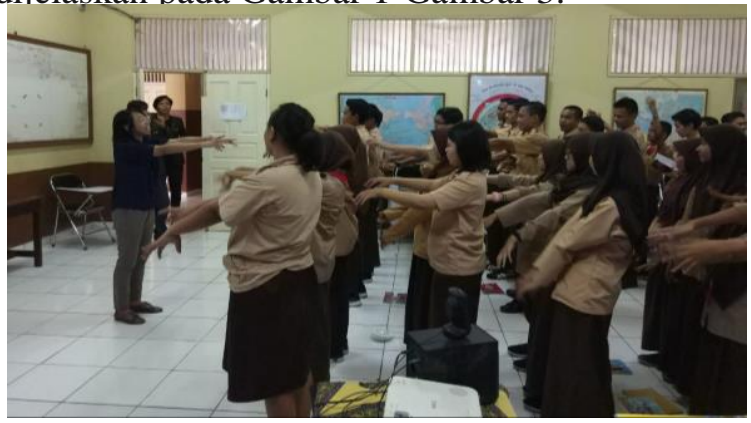

Gambar 1 Kegiatan Pembukaan Acara

Sesi berikutnya dilakukan dengan metode FGD atau focus group discussion. Focus group discussion dilaksanakan dalam 2 sesi, yang terdiri dari Diskusi Pengelompokkan jenis sampah dan dilanjutkan dengan Pemilahan jenis sampah. Fasilitator berperan sebagai pengawas kegiatan FGD (focus group discussion) yang dilakukan oleh para siswa sekolah dasar. Jumlah fasilitator ialah 4 orang, masing-masing mendampingi 1-2 kelompok FGD (focus group discussion).

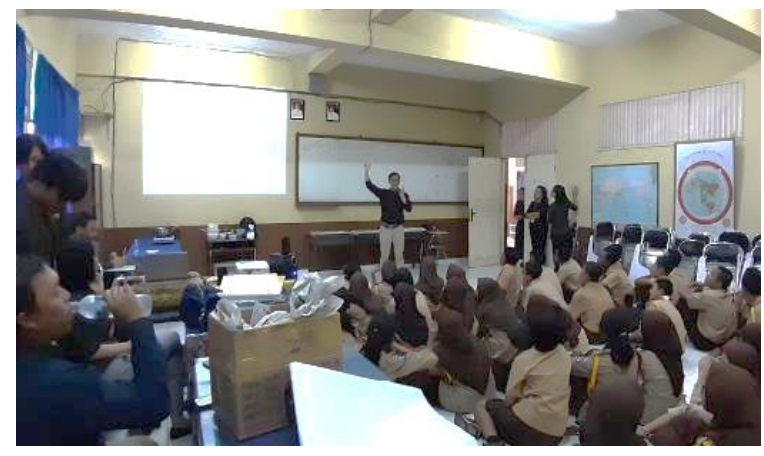

Gambar 2. Penyampaian Informasi Mengenai Sampah di Lingkungan Sekitar

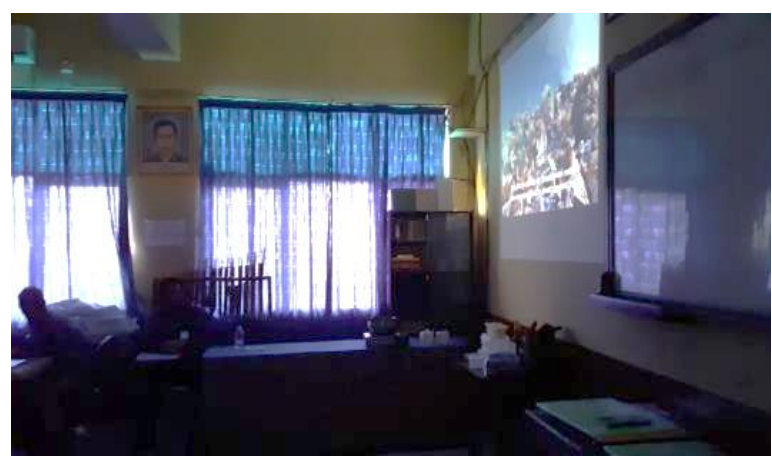

Gambar 3. Menonton Film Dokumenter Pengelolaan Sampah

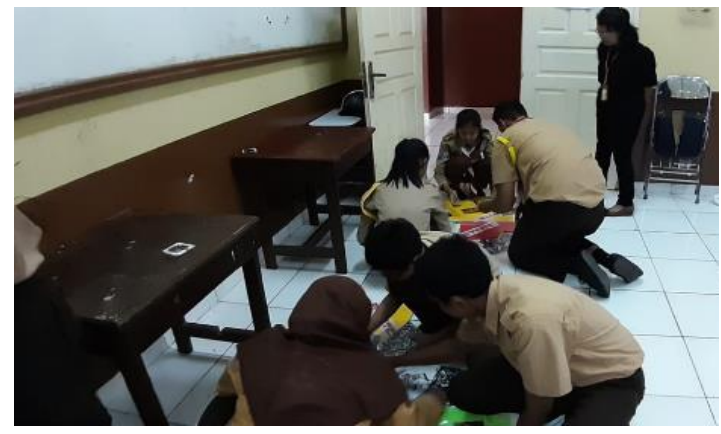

Gambar 4. Permainan / games pemilahan sampah

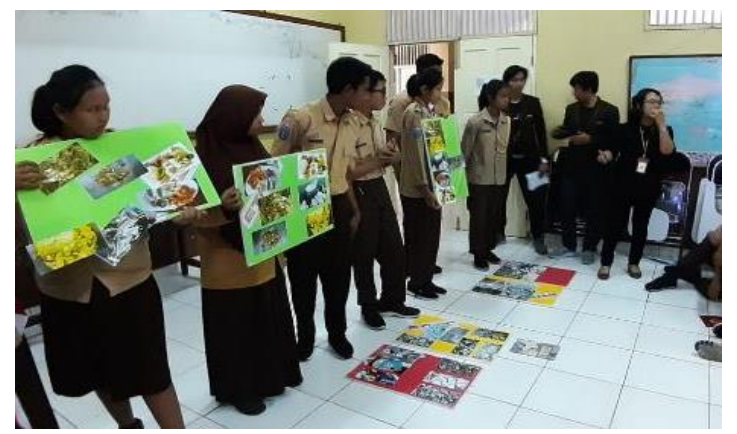

Gambar 5. Melakukan Diskusi Bersama setelah sesi games

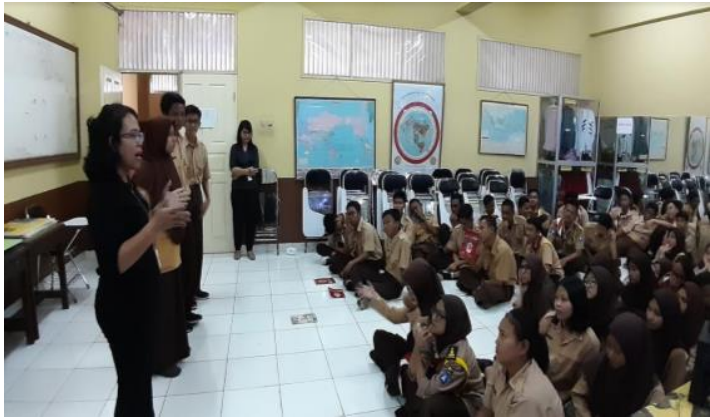

Gambar 6. Review Mengenai Kegiatan Edukasi Pengelolaan Sampah

Sesi terakhir penyampaian materi ialah berupa kegiatan diskusi bersama dengan cara melakukan pembahsan hasil FGD (Focus Group Discussion) yang sudah dihasilkan oleh setiap kelompok siswa. Kegiatan ini dijelaskan pada Gambar 4 - Gambar 6. Para peserta kegiatan yang merupakan siswa dipandu untuk menemukan kesimpulan bersama mengenai pemahaman Lingkungan Hidup dan Bencana 655 
mengenai jenis dan kategori sampah, cara pengolahan sampah, hingga bahaya yang dapat ditimbulkan dari keberadaan sampah di lingkungan.

\section{HASIL DAN PEMBAHASAN}

\section{Pembahasan Kegiatan PkM-TMMD}

Kegiatan dibuka dengan memberikan overview sampah di lingkungan sekitar, mulai pada pukul 09.00 WIB. Dalam sesi ini diawali dengan pengenalan terhadap sampah, terutama sampah yang ada di lingkungan sekitar, baik di lingkungan sekolah maupun lingkungan rumah. Para siswa menengah atas juga diajak untuk mengenal apa saja jenis dan kategori sampah yang ada di lingkungan sekitarnya.

Rangkaian acara selanjutnya dilaksanakan pukul 09.25 WIB, diisi dengan presentasi tentang sampah di lingkungan sekitar dan bahaya penumpukan sampah bagi lingkungan oleh Ibu Marchelia Gupita Sari, S.T., M.Arch,. Pada sesi yang kedua ini, siswa/i diberikan penjelasan mengenai jenis dan kategori sampah yang ada di lingkungan sekitar serta siswa/i diberikan edukasi mengenai cara pemilahan, pengolahan sampah dan mengurangi sampah yang baik dan benar. Siswa/i juga diberikan penjelasan bagaimana bahaya sampah dan kerusakan alam yang terjadi jika sampah tidak dikelola dengan baik.

Acara Pemutaran film dokumenter tentang bahaya sampah ditayangkan pada pukul 09.45 WIB. Pada sesi ini siswa/i diberikan gambaran berupa film mengenai bahaya sampah yang mengancam alam dan gambaran bagaimana cara mengurangi sampah agar tidak terjadi kerusakan alam akibat bahayanya sampah.

Selesainya pemutaran film documenter pada pukul 10.00 WIB, maka acara dilanjutkan dengan Focus Group Discussion yang dikemas dengan tema Permainan, yaitu Pengelompokan Jenis Sampah dan Pemilahan nya oleh Ibu Anisza Ratnasari, S.T., M.Sc,. Pada sesi games ini siswa/i dibagi menjadi 3 kelompok, masing-masing kelompok diberikan gambar berupa jenis-jenis sampah dan setiap kelompok harus mengelompokkan jenis dan kategori sampah apa saja yang termasuk kedalam organik, anorganik, dan sampah B3 (sampah berbahaya dan beracun) dengan benar serta dan bagaimana pemilahannya.

Sesi terakhir berupa review dan pembagian doorprize. Setelah selesai sesi games maka berlanjut pada review games, para dosen akan melihat kelompok mana saja yang berhasil memilih sampah sesuai jenis dan kategori, serta pemilahannya. Setelah itu masing-masing kelompok akan menerima doorprize untuk mengapresiasi dalam keikutsertaan dalam games ini.

Serangkaian kegiatan edukasi yang sudah dilakukan, yaitu; presentasi tentang sampah di lingkungan sekitar dan bahaya penumpukan sampah bagi lingkungan, pemutaran film dokumenter tentang bahaya sampah serta permainan/games tentang pengelompokan jenis sampah dan pemilahannya pengukuran untuk mengetahui pemahaman mereka terhadap pemilahan. Dari kegiatan tersebut, diharapkan ada pemahaman baru yang didapatkan oleh siswa tentang arti pentingnya membuang dan memilah sampah berdasarkan jenis dan kategorinya untuk kemudian bisa dilakukan kegiatan pengolahan sampah yang dapat memberikan nilai tambah. Untuk mengetahui ketercapaian / pemahaman sebelum dan sesudah siswa memperoleh kegiatan edukasi, dibagikan kuesioner yang berisi 20 pertanyaan tentang jenis dan kategori sampah, cara pengolahan sampah dan bahaya lanjut sampah di sekitar lingkungan. Berikut gambaran kegiatan pengisisan kuesioner ditunjukkan pada Gambar 7, dan konten kuesioner dipaparkan pada Tabel 2 - Tabel 4.

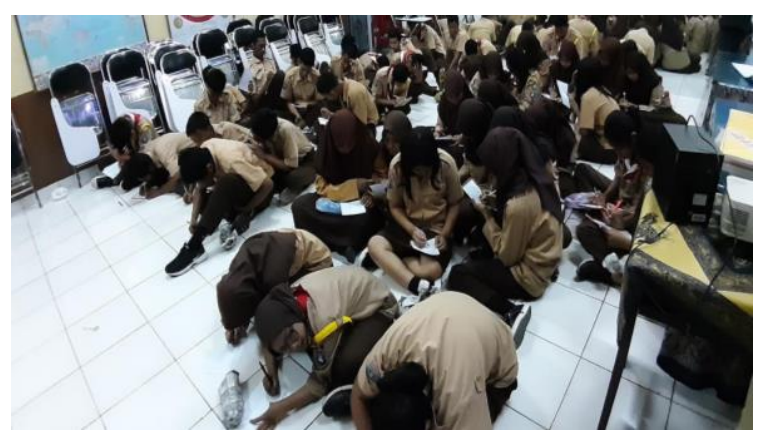

Gambar 7. Pengisisan Kuesioner oleh Peserta Kegiatan

Tabel 2. Kuesioner I untuk Peserta Kegiatan Jenis dan kategori sampah 
1 Tahukah kamu sampah organik dan anorganik ?

2 Tahukah kamu sampah B3 ?

3 Kaleng dan plastik termasuk kedalam sampah anorganik?

4 Botol hairspray bekas, aki bekas dan obat-obatan kadaluarsa termasuk kedalam sampah B3 ?

5 Sampah rumah tangga termasuk sampah organik ?

6 Pupuk kompos merupakan pengolahan sampah organik?

7 Adakah sampah kayu, kertas dan tisu termasuk kedalam sampah organik?

8 Apakah sampah styrofoam dan popok instan termasuk kedalam sampah organik kering ?

9 Apakah anda mengetahui jenis sampah yang berada di lingkungan rumah ?

Tabel 3. Kuesioner II untuk Peserta Kegiatan Cara pengolahan sampah

1 Mengurangi penggunaan plastik sebagai kemasan adalah upaya mengurangi sampah plastik ?

2 Tahukah kamu cara pengolahan sampah 3R (reuse, reduce, recycle)?

3 Membawa tote bag dan botol minum merupakan salah satu cara mengurangi sampah plastik?

4 Apakah kamu pembuang sampah terpisah sesuai dengan jenisnya?

5 Apakah anda telah melakukan pemilahan sampah di rumah?

Tabel 4. Kuesioner III untuk Peserta Kegiatan Bahaya lanjut sampah disekitar

1 Sudahkah kamu tahu bahaya membuang sampah sembarangan?

2 Anda peduli terhadap kondisi sampah saat ini ?

3 Apakah anda pernah diberikan pemahaman mengenai cara mengelola sampah yang baik dan benar?

4 Pernahkah anda mendapatkan informasi dari televisi, sosial media, dan sekolah mengenai sampah ?

5 Apakah anda mengetahui dampak pada lingkungan jika sampah dibuang sembarangan?

6 Jika kondisi lingkungan yang bruruk akibat sampah akan menimbulkan penyakit?
Berdasarkan kuesioner tersebut tersebut, diperoleh hasil bahwa sebagian besar siswa (86\%) mengerti jenis dan kategori sampah. Mereka tahu kategori sampah organik, anorganik dan sampah B3 (Bahan Berbahaya dan Beracun). Data menunjukkan bahwa pemahaman mereka tentang pengolahan sampah, yaitu mengurangi, menggunakan kembali dan mengolah kembali (3R; reduce, reuse, recycle) hampir berimbang, yaitu sebanyak 24 siswa (54\%) tidak tahu cara mengolah sampah dan sebesar 21 siswa $(46 \%)$ tahu cara mengolah sampah. Sedangkan, untuk kategori pemahaman tentang bahaya lanjut dari sampah di sekitar mereka, sebesar 29 siswa (65\%) memahami bahaya lanjut sampah. Berikut merupakan ilustrasi diagram hasil kuesioner yang dilakukan kepada para siswa.

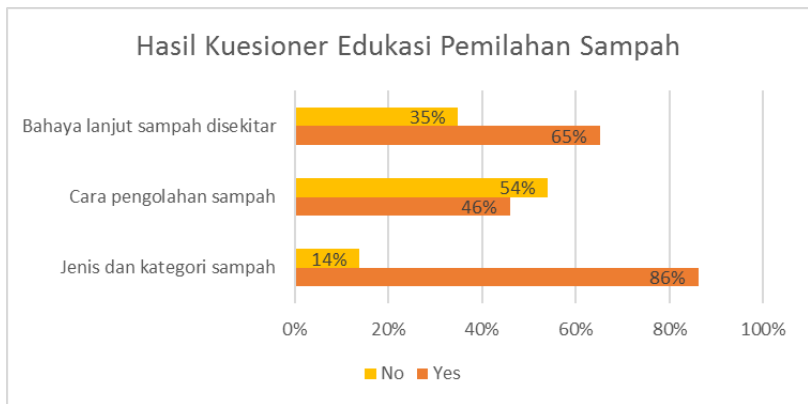

Gambar 8 Diagram Hasil Kuesioner

Harapan kedepannya, dengan adanya edukasi ini siswa bisa mempraktekkan cara pemilahan dan pengolahan sampah. Aksi dan perilaku sederhana yang paling kecil di lingkungan sekitar mereka akan tertular ke sekitar, keluarga, saudara, teman dan masyarakat sekitarnya.

\section{Hasil Kegiatan PkM-TMMD}

Pelaksanaan program pengabdian di SMA Yadika 10 Tangerang berjalan dengan baik. Program pengabdian berupa edukasi pemilahan sampah dengan metode diskusi perlu terus diupayakan mengingat produksi sampah di lingkungan sekolah maupun rumah yang semakin banyak. Hal ini disebabkan rendahnya kesadaran $3 \mathrm{R}$, yaitu reuse (memakai kembali barang bekas yang masih bisa dipakai), reduce (berusaha mengurangi sampah), dan recycle (mendaur ulang sampah agar dapat dimanfaatkan).

Lingkungan Hidup dan Bencana 
Dalam rangka mencari penyelesaian masalah sampah secara tepat, maka pada kegiatan pengabdian ini dilakukan pelatihan penggolongan tipe sampah diajarkan sedini mungkin dan dimulai dengan lingkungan sekolah. Dari acara yang telah dilakukan, hasil yang didapat yaitu semakin bertambahnya pengetahuan berupa pemahaman mengenai cara pemilahan dan pengolahan sampah yang baik serta bagaimana cara mengurangi sampah agar tidak terjadinya pencemaran dan kerusakan lingkungan. Acara ini pula merupakan salah satu upaya dalam mencegah terjadinya kerusakan alam akibat pembuangan sampah yang tidak teratur dan sembarangan.

Secara keseluruhan kegiatan pelatihan pengelolaan sampah lingkungan sekitar khususnya sekolah, dengan metode ceramah dan FGD (Focus Group Discussion) dinilai berhasil. Keberhasilan ini selain diukur dari kesesuaian rencana jadwal penyampaian materi edukasi dengan proses pelaksanaan. Selain itu target pemahaman materi yang telah diberikan bagi peserta, yang dinilai dari pengisisan kuesioner, juga telah berhasil tersampaikan. Pemahaman yang dicapai antara lain perihal jenis dan kategori sampah, cara pengolahan sampah, hingga bahaya yang dapat ditimbulkan dari keberadaan sampah di lingkungan sekitar. Dengan demikian, tujuan kegiatan ini telah tercapai.

\section{KESIMPULAN}

Serangkaian dari kegiatan acara edukasi yang telah dilakukan dengan baik atas dukungan dari semua pihak yang telah terlibat dalam acara maupun penyusunan laporan. Kegiatan PKM-CSR ini masih jauh dari kesempurnaan, oleh karena itu penulis mengharapkan partisipasinya dari semua pihak dan saran yang membangun dalam penyempurnaan acara selanjutnya.

Agar pelaksanaan acara berikut dapat berjalan dengan baik dan lancar, penulis memiliki Beberapa saran, antara lain: 1) meningkatkan kesadaran untuk membuang sampah pada tempatnya; 2) mengurangi sampah yang berasal dari plastic; 3) menggunakan barang yang ramah lingkungan.

Selain saran berupa peningkatan keawasan terhadap sampah bagi peserta kegiatan, program kegiatan Pengabdian kepada Masyarakat (PkM) ini diharapkan dapat dilanjutkan pada tahun-tahun berikutnya di lokasi yang lain untuk menunjang kelestarian lingkungan sekitar, khususnya area sekolah. penyempurnaan dan peningkatan pemahaman bagi peserta pelatihan diharapkan dapat dilengkapi dengan metode demonstrasi serta pemberian kesempatan untuk tanya jawab intensif, selain penerapan metode ceramah dan sesi permainan

\section{UCAPAN TERIMAKASIH}

Rasa terimakasih kami sampaikan kepada Prof. Richardus Eko Indrajit selaku rector, dan Prof. Harianto Hardjasaputra selaku wakil rektor 1 bidang akademik Institut Sains dan Teknologi Pradita, atas dukungan, kebijakan dan pengarahan dalam penyusunan kegiatan PKM-TMMD (Pengabdian Kepada Masyarakat dan TNI Manunggal Membangun Desa).

Ucapan terima kasih juga kami sampaikan kepada Program Studi Arsitektur Institut Sains dan Teknologi Pradita yang telah mendukung dan mendanai kegiatan ini beserta tim dosen dan mahasiswa yang telah terjun bersama dalam melaksanakan kegiatan edukasi mengenai sampah di lingkungan sekitar dan penyuluhan pemilahan sampah.

Selain itu, ucapan terimakasih juga kami tujukan kepada TNI (Tentara Republik Indonesia) yang telah melibatkan tim akademisi sebagai satuan tugas (satgas) kegiatan non-fisik TMMD ke-105 di Tangerang.

Kemudian ucapan terimakasih juga kami sampaikan kepada pihak pimpinan, segenap pengurus, bapak-ibu guru dan siswa/siswi SMA/K Yadika 10 Tangerang yang telah berpartisipasi dan mensukseskan pelaksanaan kegiatan serta semua pihak yang tidak dapat kami sebutkan satu persatu

$$
\text { Lingkungan Hidup dan Bencana } \quad 658
$$


yang telah membantu terlaksananya kegiatan pengabdian kepada masyarakat $(\mathrm{PkM})$ ini.

Demikian ucapan terima kasih kepada segenap pendukung keberhasilan acara PKM-TMMD yang masih jauh dari sempurna ini, diharapkan kegiatan ini dapat terasa manfaatnya bagi pelaku kegiatan dan dapat dirasakan lebih luas oleh seluruh lapisan masyarakat.

\section{REFERENSI}

Singhirunnusorn, W., Donlakorn, K.,dan Kaewhanin, W. (2012). Household Recycling
Behaviours and Attitudes toward Waste Bank Project: Mahasarakham Municipality. Journal of Asia Behavioural Studies, 2(6):35-47.

Trina,E.,Tallei, T.E., Iskandar, J.,Runtuwene, S.,dan Filho, W.L. (2013). Local Community based Initiativesof Waste Management Activities on Bunaken Island in North Sulawesi, Indonesia. Research Journal of Environmental and Earth Sciences, 5(12):737-743

Undang-Undang Republik Indonesia No. 18

Tahun 2008 Tentang Pengelolaan Sampah 